\title{
The Quality Analysis of Financing and Funding On the Performance of Bank Syariah Mandiri Jember Area of 2015 - 2019
}

\author{
${ }^{1}$ Barid Paladin Apramada ${ }^{*}{ }^{2}$ Isti Fadah, ${ }^{3}$ Sumani \\ ${ }^{1,2,3}$ Faculty of Economics and Business, Jember University Kalimantan Road No. 37, Jember 68132, \\ Indonesia
}

\begin{abstract}
In general, this study aims to analyze the Quality of Funding and Funding Against the Performance of Sharia Bank Mandiri in Jember Area for the Period 2015 - 2019. The population of this study is the quarterly financial statements of Bank Syariah Mandiri in Jember Area in 8 branches from 2015 to 2019. The sample is part of a population object that represents its population characteristics. The sampling design in this study was by means of the census method, namely the population being the study sample, so that collected $8 \times 5 \times 4=160$ data analysis. Hypothesis testing uses multiple linear regression analysis test tools. After analyzing the data, several conclusions can be drawn, namely: the quality of current productive assets partially has a significant positive effect on the performance of Bank Syariah Mandiri in Jember Area, which is proxied by ROA, the quality of productive assets under special attention partially has a significant negative effect on the performance of Bank Syariah Mandiri in Jember Area, the quality of substandard productive assets partially has a significant negative effect on the performance of Bank Syariah Mandiri Area Jember, the quality of productive assets is doubtful partially has a significant negative effect on the performance of Bank Syariah Mandiri Area Jember, the quality of the nonproductive assets partially has a significant negative effect on the performance of Bank Syariah Mandiri In Jember Area, funding proxied by DPK partially has a significant positive effect on performance.
\end{abstract}

Keywords: Financing Quality, Funding and Performance.

\section{Introduction}

Sharia Commercial Banks, large assets, large profits should be, but not comparable with the assets and profits of sharia business units. In the philosophy of credit repayment, there are two basic analyzes of debtors in lending, namely good faith / willingness of payment and ability of payment, in order to determine the character of a prospective debtor, a quantitative track record is needed to evaluate the quality of credit history. Prospective debtors marked through checking collectibility. This initial phase is called prescreening, which every debtor must pass.

Based on SE OJK No. / SEOJK.03/2015 Concerning the Asset Quality Assessment of Sharia Commercial Banks and Sharia Business Units, the quality of financing is determined in 5 (five) assessment categories, namely current, special attention, substandard, doubtful and loss. Collectibility 1 or Col. 1 with hashtag (Current) is the highest collectibility status classified as Performing Financing (PF) and is marked from the payment history of principal installments and the monthly margin is exact or less than the due date of monthly payments (flawless). Collectibility 1 represents the good character / character of the debtor because of the smooth payment of his obligations. Collectibility 2 with hashtag (Special Mention) which is popular in the banking world abbreviated as DPK, is a collectibility status classified as Performing Financing (PF) which is marked by the delay in paying debtors beyond the due date not exceeding 90 (ninety) days. The determination of the DPK status manually is also given if the debtor is still considered to have a good cash flow but is less able to pay his obligations. In banking practice, bank deposits are generally considered bad even though theoretically they are still classified as PF. Settlement of problem financing with Collectibility 2 status can be done through regular billing or carrying out restructuring depending on the agreement between the debtor and the creditor. 
Collectibility 3 with hashtag (Substandard) is the collectibility status of the debtor who is late paying more than 90 (ninety) days from the monthly due date up to 180 (one hundred eighty) days. Determination of the Collectibility 3 status manually can be given by the bank if the debtor still has good faith even though the ability to pay is inadequate, but the bank believes the debtor still has a fairly good cash flow. At this stage of the status, the bank issues a Warning Letter (SP) and starts calculating the accruals of principal arrears and current margins, current penalty arrears, accounting administrative arrears, and other arrears through the issuance of factoring. If it still allows the debtor to be able to pay their obligations, the restructuring can be carried out. Collectibility 4 with hashtag (Doubtful) is a collectibility status indicating late payment exceeding 180 days from the due date up to 270 (two hundred seventy) days. At this stage of the collectibility status, the bank must take the assumptions on principal installments and unpaid margins and prepare to draw conclusions on the settlement of problem financing through auction of collateral and submission of insurance financing if any. At this stage, collectibility 4 can be shifted manually to collectibility 5 if the bank has gained confidence that the debtor is not only unable to pay its obligations, but does not have the good faith to settle its obligations. At this stage also, the bank is obliged to issue SP-2 and SP-3 to debtors.

Collectibility 5 with hashtag (Loss) is the lowest collectibility classified as Non Performing Loan (NPL) which represents principal installments and margins that have exceeded 270 (two hundred seventy) days not paid and the bank is obliged to carry out the most recent problem financing financing, namely auctioning collateral for close PPAP that is formed $100 \%$ of productive assets to cover the worst credit risk. This collectibility status is more popular as bad credit. Banks have the right to auction collateral after issuing Warnings (SP) 3 times, issuing factoring, and reporting credit handling and settlement history, starting from billing history, negotiation, and restructuring (if any). The total NPL or NPF in a banking work unit is required to be below 3\% as a Col-5 coverage threshold. At a macro level, if left unchecked, the monetary economy in Indonesia could deteriorate and have a trickle down effect on the overall economy.

Hidayat et al. (2012) found that deregulation that encouraged banks to be more involved in non-traditional activities could adversely affect the overall banking system where large banks play an important role in banking.

in Indonesia. Barry (2016) found that banks with lower levels of non-interest income and higher income concentrations were less risky, consistent with previous international evidence. Evidence was also found to support an increase in risk because the effects were too large to fail, with this increase in risk offset by a decrease in the risk of large banks after the 2007-2008 crisis. Non-interest income is generally considered to be an increased risk, but certain types of non-interest income are reduced by risk when the effects of bank specialization are considered. It was also found that the 2008 financial crisis changed several aspects of the relationship between bank risk and revenue composition. Asiyah (2017) found that 1) The quality of the productive assets smoothly gave a positive and significant effect on $\alpha 5 \%$ on profitability 2) The quality of the productive assets under special attention had a negative and significant effect on $\alpha 5 \%$ on profitability 3 ) The quality of the productive assets substandard gave negative but not significant effect on $\alpha 5 \%$ on profitability 4) The quality of productive assets is doubtful but has a positive but not significant effect on $\alpha=$ $5 \%$ on profitability 5) The quality of bad productive assets gives a negative but not significant effect on $\alpha$ $5 \%$ on profitability.

The purpose of providing Islamic bank financing, including for; a) improving the economy of the people, meaning that people who cannot access economically, with the financing they can do economic access. Thus, it can improve its economic level; b) availability of funds for business improvement, meaning that for business development requires additional funds. These additional funds can be obtained from financing activities.

The party with a surplus of funds distributes to the party minus the funds, so that it can be rolled out; c) increase productivity, meaning that the financing provides opportunities for the business community to be able to increase their production power. Because production efforts will not work without funds; d) opening new jobs, meaning that with the opening of business sectors through the addition of funding funds, the business sector will absorb labor. This means adding or opening new jobs; e). income distribution occurs, meaning that productive business communities are able to carry out work activities, meaning they will get 
income from the results of their efforts. Income is part of community income. If this happens, income will be distributed.

Third Party Funds are funds raised from the community in the form of savings, time deposits and demand deposits. The funds raised from the community are used by banks to expand credit and investment. Deposits are important for banks because the more funds raised can increase bank profitability through the difference between credit interest and deposit interest. Funding in this study was proxied by collections 1 to 5, while funding was proxied by Third Party Funds.

PT Bank Syariah Mandiri (BSM) is one of the sharia banks in Indonesia in the form of Sharia Commercial Banks, officially started operating on November 1, 1999. Previously it was a bank conventional named PT Bank Susila Bakti (BSB), which is owned by the Employee Welfare Foundation (YKP) of PT Bank Dagang Negara and PT Mahkota Prestasi. BSM Jember area as an extension of management in services to customers includes work areas in Jember, Banyuwangi, Situbondo, Bondowoso and Lumajang districts.

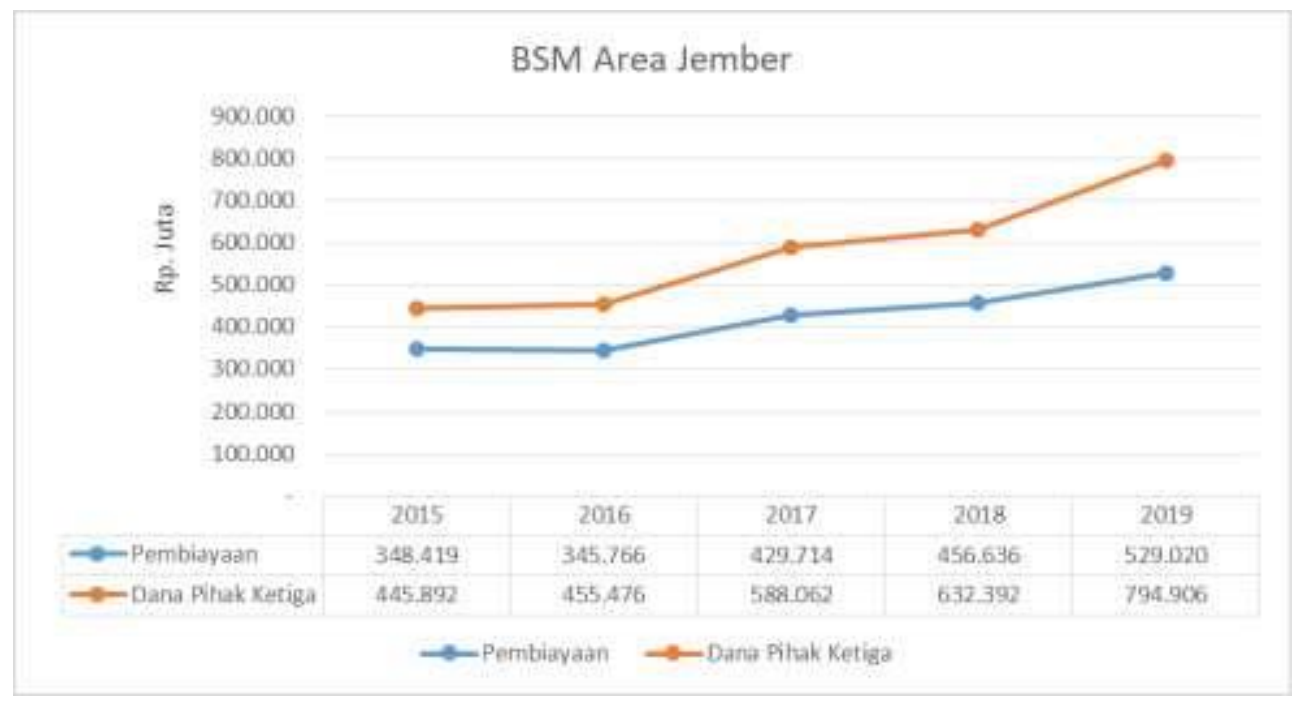

Figure 1: Bank Syariah Mandiri Area Jember Performance (Source: BSM)

Funding in this study is proxied by collections 1 to 5 , while funding is proxied by Third Party Funds. Based on the formulation of the problem, the purpose of this study is to partially analyze the effect of the quality of current assets on the performance of Bank Syariah Mandiri Area Jember; earning asset quality in particular attention to the performance of Bank Syariah Mandiri Area Jember; the quality of earning assets is substandard against the performance of Bank Syariah Mandiri Area Jember; the quality of earning assets is doubtful about the performance of Bank Syariah Mandiri in Jember Area; the quality of the non-earning assets against the performance of Bank Syariah Mandiri Area Jember; and funding for the performance of Bank Syariah Mandiri Area Jember;

\section{Literature Review}

\subsection{Financing}

Financing is the provision of facilities to provide funds to meet the needs of parties who are devisit units (Antonio, 2001: 160). Financing or financing is funding provided by one party to another party to support planned investments, both alone and institutions (Rival and Arifin, 2010: 681). Or financing is the provision of funds or claims equivalent to that in the form of:

a. Transactions in the form of mudharabah and musyarakah.

b. Lease transactions in the form of ijarah or lease purchases in the form of ijarah muntahiya bittamlik.

c. Buying and selling transactions in the form of mudharabah, salam and istishna receivables '

d. Lending and borrowing transactions in the form of Qard, and

e. Service leasing transactions in the form of ijarah for multi-service transactions.

In the narrow sense, financing is used to define funding carried out by financial institutions such as Islamic banks to the customer. Funding broadly means financing or expenditure, which is funding spent to support planned investments, either done alone or done by others. 
Sharia financing in general the activities of a bank include raising funds from the public in the form of savings, current accounts and deposits, then channeling these funds to the public in the form of credit or financing, as well as other financial services activities. Financing is an activity of an Islamic bank in channeling funds. to the customers who need funds. Financing is very useful again Islamic banks and BMT, customers, and the government. Funding provides a large yield among other funds channeled by Islamic banks. Before channeling funds through financing, Islamic banks need to conduct an in-depth financing analysis. So that losses can be avoided. Funding is the activity of Islamic banks in channeling funds to parties other than based on sharia principles.

Earning Assets Quality is divided into 5 parts, namely:

a. Collectibility 1 represents the good character / character of the debtor because of the smooth payment of his obligations.

b. Collectibility 2 or col 2 with the hashtag (Special Mention) which is popular in the banking world abbreviated as DPK, is a collectibility status classified as Performing Loan (PL) which is characterized by delays in paying debtors beyond the due date up to 90 days from the due date.

c. Collectibility 3 or collectable 3 with hashtags (Substandard) is the collectibility status of debtors who are late paying more than 90 days from the monthly due date until at least 180 days.

d. Collectibility 4 or collectable 4 with hashtag (Doubtful) is a collectibility status that indicates a delay in paying more than 180 days from the due date up to 270 days. At this stage of the collectibility status, the bank must take the assumption of the principal installment and non-interest loan and be ready to draw conclusions on the settlement of problem loans through collateral auction. At this stage, Collectibility 4 can be shifted manually to Collectibility 5 if the bank has gained confidence that the debtor is not only unable to pay its obligations, but does not have the good faith to settle its obligations.

e. Collectibility 5 or collateral 5 with hashtag (Loss) is the lowest collectibility classified as Non Performing Loan (NPL) which represents principal installments and non-paid loan interest and the bank is obliged to carry out the most recent problem loans settlement, namely auctioning collateral to form $100 \%$ of PPAP. earning assets to cover the worst credit risk.

Unlike the definition of credit which requires the debtor to return the loan by providing interest to the Bank, the financing is based on the sharia principle of returning the loan with profit sharing or margin based on an agreement between the Bank and the debtor. For example, financing with the principle of buying and selling is aimed at owning goods, while those using the lease principle are intended to obtain services.

From the above understanding, it can be explained that the purpose of financing is to increase business capital either credit or financing can be in the form of money or bills whose value is measured by money. Then there is an agreement between the bank (creditor) and the customer receiving the financing (debtor), with an agreement that has been made and agreed upon.

In financing, it has several functions that are very diverse, because the existence of Islamic banks that run financing based on Islamic principles is not only to seek profits and enliven the banking business in Indonesia, but also to create a safe business environment, including:

a. Providing financing using sharia principles that apply a profit sharing system that does not burden the debtor.

b. Helping poor people who are not touched by conventional banks because they are unable to meet the requirements set by conventional banks.

c. Helping economically weak people who are always played by loan sharks by helping through funding for the business done.

In addition to the above functions, there are other functions related to a financing, including:

a. Increasing the efficiency of money Savers save their money in the bank in the form of demand deposits, savings, and deposits. The money in a certain percentage is increased its usefulness by the bank for an effort to increase productivity.

b. Increase the usability of goods. Producers with financial assistance can convert raw materials into finished materials so that the utility of these materials increases. 
c. Increase money circulation. Funding channeled through the accounts of the entrepreneur's newspaper creates an increase in the circulation of demand deposits and the like such as checks, crossed checks, money orders, and so on. Through financing circulation of currency and demand deposits will be more developed because financing increases an excitement to try so that the use of money will improve qualitatively let alone quantitatively Calculation in asset quality.

\subsection{Funding}

Funding in banks comes from Third Party Funds. Third party funds are very important for banks in collecting funds, because basically for the business interests of banks collecting funds from the bank itself (first party), funds from other parties (second party funds) and funds from the public or third parties in the form of savings, deposits and other sources of funds.

According to Kasmir (2012: 53) the definition of third-party funds is as follows: "Third-party funds are funds that are trusted by the public to banks in the form of demand deposits, time deposits, certificates of deposit, savings or which can be likened to it". Furthermore, the definition of third party funds according to Dendawijaya (2009: 24) is as follows: "Third party funds (DPK) are funds sourced from the public, the largest source of funds most relied on by banks. Banks can use these funds to become income, by channeling funds. Banks can distribute funds to community in the form of financing.

The greater income generated by banks, means that the greater the opportunity for banks to generate profits so that banks will be more interested in increasing the amount of distribution of funds to the public ". Meanwhile according to ismail (2010: 43) the definition of third party funds is as follows: "Third party funds are usually known by the name of community funds are funds collected by banks that come from the community in a broad sense, covering individual communities, as well as business entities".

Based on the above understanding it can be concluded that the understanding of third party funds is funds deposited by the public in the form of demand deposits, time deposits certificates of deposit, savings or can be likened to it, marked by an agreement or agreement and then the funds are collected by banks. Indicators of these third party funds according to Ismail (2010: 43), namely:

DPK $=$ current account + savings + deposit

Measurement of third party funds can be calculated using the formula (Dendawijaya, 2009: 49):

DPK $=($ Third Party Funds $) \times 100 \%$ Total Obligations

Meanwhile according to Kasmir (2012: 75) the calculation of Third Party Funds (DPK) as a whole can be stated as follows:

DPK = Wadiah Current Account + Wadiah Savings + Mudharabah Savings + Mudharabah Current Account Based on the foregoing, it can be stated that the indicator of third party funds is the amount of current accounts, savings and deposits.

In banking, funds originating from the public or third party funds are the most important source of funds for bank operations and are a measure of the success of a bank if it is able to finance its operations from this source of funds. Listed below are several types of third party funds according to Banking Law Number 10 of 1998 dated November 10, 1998.

a. Demand Deposit (Demond Deposit). Deposits which can be withdrawn at any time by using checks, crossed checks, other means of payment orders by book-entry.

b. Savings Savings. Deposits which can be withdrawn can only be carried out according to certain agreed conditions, but cannot be withdrawn by check, giro and or other equivalent instruments.

c. Deposits Deposits which can only be withdrawn at a certain time based on the customer's saving agreement with the bank.

\subsection{Financial Performance}

Company performance can be said as a formal effort carried out by the company to evaluate the efficiency and effectiveness of the company's activities that have been carried out in a certain period of time. Determination of certain measures that can measure the success of an organization or company in generating profits (Sucipto, 2003: 6). 
To find out the company's financial performance in general it is necessary to do an analysis of the financial statements, which include (1) comparison of company performance with other companies in the same industry and (2) evaluation of the tendency of the company's financial position over time. The company's financial statements report both the company's position at a certain time and its operations duringseveral periods ago (Brigham and Houston, 2010: 78).

From the above understanding it can be concluded that financial performance is a formal effort that has been carried out by a company that can measure the company's success in generating profits, so that it can see the prospects, growth, and the potential for good development of the company by relying on existing resources. A company can be said to be successful if it has achieved the standards and objectives set.

Performance measurement is used by companies to make improvements over their operational activities in order to compete with other companies. Financial performance analysis is a critical review process of reviewing data, calculating, measuring, interpreting, and providing solutions to the company's finances in a certain period. Financial performance can be assessed with several analytical tools. Based on the technique, financial analysis can be divided into 8 (eight) types, according to Jumingan (2006: 242), namely:

a. Comparative Analysis of Financial Statements, an analytical technique by comparing financial statements of two or more periods by showing changes, both in number (absolute) and in percentage (relative).

b. Trend Analysis (position tendency), is a technique of analysis to determine whether the financial situation is showing an increase or decrease.

c. Percentage Analysis per Component (common size), is an analysis technique to find out the percentage of investment in each asset against the whole or total assets or debt.

d. Analysis of Sources and Use of Working Capital, is an analysis technique to determine the magnitude of sources and uses of working capital through two time periods that are compared.

e. Analysis of Cash Sources and Uses, is an analysis technique to determine the condition of cash accompanied by changes in cash in a certain time period.

f. Financial Ratio Analysis, is a financial analysis technique to determine the relationship between certain items in the balance sheet and the income statement both individually and simultaneously.

g. Analysis of Changes in Gross Profit, is an analysis technique to determine the position of earnings and the causes of earnings changes.

h. Break Even Analysis, an analysis technique to determine the level of sales that must be achieved so that the company does not experience losses.

The hypotheses in this study are:

H1: The quality of current assets is partially a significant positive effect on performance.

$\mathrm{H} 2$ : The quality of productive assets under special attention partially has a significant negative effect on performance.

H3: The quality of substandard productive assets partially has a significant negative effect on performance.

H4: The quality of earning assets is doubted as having a significant negative effect on performance.

H5: The quality of the non-productive earning assets partially has a significant negative effect on performance.

H6: Partial funding has a significant positive effect on performance.

\section{Methodology}

Based on the research objectives, namely to analyze the quality of financing and funding on performance, this research is explanatory research. The population of this study is the quarterly financial statements of Bank Syariah Mandiri Area Jember in 8 branches from 2015 to 2019. The sample is part of the population object that represents the characteristics of the population. The sampling design in this study was by means of the census method, namely the population being the study sample, so that collected $8 \times 5 \times 4=160$ data analysis. The independent variables used in this study are: $\mathrm{Y}=$ Performance (ROA). Endogenous variables: $\mathrm{X} 1$ = Quality of current productive assets, $\mathrm{X} 2$ = Quality of productive assets under special attention, X3 = 
Quality of substandard productive assets, X4 = Quality of productive assets is doubtful, X5 = Quality of non-productive earning assets, and X6 = Third Party Funds, are funds entrusted by the public to banks based on fund storage agreements in the form of demand deposits, deposits, certificates of deposit, savings and or other equivalent forms. The analytical tool used is multiple linear regression analysis. The model can be stated as follows:

Model:

$\mathrm{ROA}=\mathrm{b} 0$ +b1KAPL +b2KAPDPK +b3KAPKL +b4KAPD +b5KAPM + b6DPK +e2

\section{Results and Discussion}

\subsection{Research Results}

Regression analysis relates to the study of the dependence of a dependent variable on one or more independent variables with the aim of finding out how much influence the independent variables are, the quality of current productive assets, the quality of productive assets under special attention, the quality of substandard productive assets, the quality of productive assets is doubtful, the quality of the non-productive assets and funding of the dependent variable, ROA. After the equation is declared BLUE, multiple linear regression analysis is performed. Regression Analysis Test Results of equation 1 can be seen in the table below:

\section{Table 1: Summary Results of Multiple Linear Regression Analysis Equation 1}

\begin{tabular}{|l|c|c|l|}
\hline \multicolumn{1}{|c|}{ Variable } & $\boldsymbol{\beta}$ & $\mathbf{T}_{\text {count }}$ & Information \\
\hline (Constant) & $-0,167$ & & \\
KAPL & 0,230 & 3,011 & Significant \\
KAPDPK & $-0,367$ & $-10,899$ & Significant \\
KAPKL & $-0,875$ & $-8,338$ & Significant \\
KAPD & $-0,731$ & $-15,549$ & Significant \\
KAPM & $-0,277$ & $-4,155$ & Significant \\
DPK & 0,318 & 3,750 & Significant \\
\hline
\end{tabular}

\section{Source: Processed Data. 2020}

Regression models based on the results of the analysis above are:

ROA $=-0,167+0,230 \mathrm{KAPL}-0,367 \mathrm{KAPDPK}-0,875 \mathrm{KAPKL}-0,731 \mathrm{KAPD}-0,277 \mathrm{KAPM}+0,318 \mathrm{DPK}$

The analysis shows the coefficient of determination or $\mathrm{R} 2=0.721$. This value shows that together the KAPKL, KAPDPK, KAPD, KAPKL, KAPM, and DPK variables have an influence on ROA of $72.1 \%$. In other words, $72.1 \%$ of changes in ROA at BSM Outlets can be explained by the quality of current productive assets, the quality of productive assets under special attention, the quality of substandard productive assets, the quality of productive assets is doubtful, the quality of non-productive earning assets and funding. Testing the regression coefficient value of each independent variable can be done by comparing between the calculated statistics and the table statistics, if tcount $>$ ttable can be said that there is a significant influence of the independent variables on the dependent variable. Testing the hypothesis of the study aims to determine whether the variable KAPKL, KAPDPK, KAPD, KAPKL, KAPM, and DPK partially influence on ROA. The $t$ test results in equation 1 are as follows:

Table 2: T Test Summary Results in Equation 1

\begin{tabular}{|l|c|c|l|}
\hline \multicolumn{1}{|c|}{ Variable } & $\mathbf{T}_{\text {count }}$ & $\mathbf{t}_{\text {table }}$ & Information \\
\hline Variabel Independen: ROA & & & \\
Variabel Dependen: & & & \\
KAPL & 3,011 & 1,975 & Significant \\
KAPDPK & $-10,899$ & 1,975 & Significant \\
KAPKL & $-8,338$ & 1,975 & Significant \\
KAPD & $-15,549$ & 1,975 & Significant \\
KAPM & $-4,155$ & 1,975 & Significant \\
DPK & 3,750 & 1,975 & Significant \\
\hline
\end{tabular}




\section{Source: Processed Data. 2020}

a. Hypothesis Testing 1. The KAPL variable has a tcount> $t$ table $(3.011>1.975)$ and has a positive parameter estimate coefficient which is indicated by a positive sign in Table 4.5 of the tcount column, thus testing showing $\mathrm{H} 1$ is accepted. These results indicate that the KAPL variable partially has a significant positive effect on ROA.

b. Hypothesis Testing 2. The KAPDPK variable has a value of tcount $>$ ttable $(-10,899>1,975)$ and has an estimated coefficient of negative parameters indicated by a negative sign in Table 4.5 of the tcount column, thus testing showing $\mathrm{H} 2$ is accepted. This result shows that KAPDPK variable partially has a significant negative effect on ROA.

c. Hypothesis Testing 3. The KAPKL variable has a value of tcount $>$ ttable $(-8,338>1,975)$ and has an estimated coefficient of negative parameters indicated by a negative sign in Table 4.5 of the tcount column, thus testing shows $\mathrm{H} 3$ is accepted. These results indicate that the KAPKL variable has a significant negative significant effect on ROA.

d. Hypothesis Testing 4. The KAPD variable has a value of tcount $>$ ttable $(-15,549>1,975)$ and has an estimated coefficient of negative parameters indicated by a negative sign in Table 4.5 of the tcount column, thus testing showing H4 is accepted. This result shows that KAPD variable significantly has a significant negative effect on ROA.

e. Hypothesis Testing 5. The KAPM variable has a value of tcount $>$ ttable $(-4.155>1,975)$ and has an estimated coefficient of negative parameters indicated by a negative sign in Table 4.5 of the tcount column, thus testing showing H5 is accepted. These results indicate that the KAPM variable has a significant negative significant effect on ROA.

f. Hypothesis Testing 6. TPF variable has a value of tcount $>$ ttable $(3,750>1,975)$ and has a positive parameter estimate coefficient which is indicated by a positive sign in Table 4.5 of the tcount column, thus testing showing H6 is accepted. These results indicate that the TPF variable has a partially significant positive effect on ROA

\subsection{Discussion}

The results of the analysis show that the quality of current productive assets partially has a significant positive effect on the performance of Bank Syariah Mandiri in Jember Area, which is proxied by ROA. The better KAPL owned by BSM, the better the performance. This indicates that BSM has managed its assets well so that it can produce maximum performance (ROA). The first hypothesis which states that the quality of current productive assets partially has a significant positive effect on performance, is accepted. The quality of earning assets falls into the current category if the principal and interest installment loans are timely, have active account mutations, and are part of loans guaranteed by cash collateral. Financial performance will improve if earning assets are well managed so that the quality of earning assets is in the current category. This is a form of accountability for third party customer funds that continues to increase, so that the trust of third party customers will continue to increase. The results of this study support research conducted by Asiyah (2017), which found that the quality of current productive assets had a positive and significant effect on $\alpha 5 \%$ on performance.

a. The results of the regression analysis showed that the quality of the productive assets under special attention partially had a significant negative effect on the performance of Bank Syariah Mandiri in Jember Area. Negative parameters indicate, if KAPDPK increases, the performance of Bank Syariah Mandiri in Jember Area will decrease. The second hypothesis which states that the quality of productive assets under special attention partially has a significant negative effect on performance, is accepted. Bank earning assets are assets owned by Bank Syariah Mandiri in Jember Area, the use of which is carried out by investing funds to economic agents and the public. Productive assets are often also referred to as earning assets or assets that produce, because the investment of these funds is to achieve the expected level of income (profit). In carrying out investment activities, earning assets can describe the performance of banks, besides earning assets also have an impact on the level of profitability (Sinungan 2006: 195). The quality of earning assets is included in the category of special attention if there are arrears on principal and / or interest installments that have not exceeded 90 days, sometimes overdrafts, relatively active account mutations, rarely violations of the contract agreed and supported by new loans. This study supports the research of Asiyah (2017), who found that the quality of productive assets under special attention had a negative and significant effect on $\alpha$ $5 \%$ on performance. 
b. The results of multiple linear regression analysis indicate that the quality of substandard productive assets partially has a significant negative effect on the performance of Bank Syariah Mandiri in Jember Area, which is proxied by ROA. The negative parameter coefficient indicates that the higher the KPAKL value at the bank, the performance (ROA) will decrease. The third hypothesis which states that the quality of productive assets is substandard partially has a significant negative effect on performance, is accepted. The quality of substandard productive assets at Bank Syariah Mandiri in Jember Area is a loan whose principal repayments and interest payments have been delayed for 3 months from the agreed time. Criteria for the quality of substandard productive assets consist of arrears in principal and / or interest installments that have exceeded 90 days, frequent overdrafts, relative frequency of account mutations, violations of contracts that have been pledged for more than 90 days, and there are indications of financial problems faced by debtors , as well as weak credit documentation. The results of this study do not support Asiyah's (2017) research, which found that the quality of substandard productive assets had a negative but not significant effect on $\alpha$ $5 \%$ on performance.

c. The analysis shows that the quality of earning assets is doubted as having a significant negative effect on the performance of Bank Syariah Mandiri in Jember Area. The negative parameter coefficient indicates that the higher the KAPD of Bank Syariah Mandiri in Jember Area, the performance proxied by ROA will decrease. This is because banks have loans whose payments have been delayed for 6 months so that it will affect the bank's performance. The fourth hypothesis which states that the quality of productive assets is doubtful partially has a significant negative effect on performance, is accepted. The quality of earning assets is doubtful as the repayment of principal and interest payments have been delayed for 6 months or twice of the agreed schedule. The quality criteria for productive assets are doubtful, consisting of: principal and / or interest arrears that have exceeded 180 days, permanent overdrafts, defaults of more than 180 days, margin capitalization, and weak legal documentation for both credit agreements and binding guarantees. The results of this study do not support research conducted by Asiyah (2017), which found that the quality of productive assets is doubtful but has a positive but not significant effect on $\alpha=5 \%$ on profitability.

d. The results of the multiple linear regression analysis showed that the quality of the non-productive earning assets partially had a significant negative effect on the performance of Bank Syariah Mandiri Area Jember, which was proxied by RAO. The negative parameter coefficient indicates that the higher the KAPM, the ROA or performance will decrease. The quality of the non-productive earning assets will result in operational losses which will result in a decline in banking performance. The fifth hypothesis which states that the quality of the non-productive assets partially has a significant negative effect on performance, is accepted. The quality of the non-earning assets is the credit whose principal repayments and interest payments have been delayed more than 1 year since the due date contains the agreed schedule. The criteria for the quality of the non-earning assets consist of: there are arrears in principal and / or interest installments that have exceeded 270 days, operational losses are covered by new loans, in terms of legal and market conditions, and guarantees cannot be disbursed at fair value. The results of this study do not support the research of Asiyah (2017) who found that the quality of the non-productive assets had a negative but not significant effect on $\alpha 5 \%$ on profitability.

e. The analysis shows that funding proxied by the TPF partially has a significant positive effect on the performance or ROA of Bank Syariah Mandiri in Jember Area. The positive parameter coefficient indicates that the greater the funding, the better the performance will be. This means that with funding, the Bank Syariah Mandiri Area Jember has the advantage of having capital that is managed again from the source of funding. The sixth hypothesis which states that funding partially has a significant positive effect on performance. Funding decisions are decisions about how to obtain funds to finance an investment. The funding function must also be carried out efficiently. So the financial manager must strive for the company to obtain the necessary funds at a minimal cost with the most favorable terms. Financial managers must carefully consider the nature and cost of each source of funds having different financial consequences. Therefore, financial managers must always look for alternative sources of funds for later analysis, and from the results of the analysis must be taken an alternative decision on the source of funds or which combination of funding sources will be chosen (Syahyunan, 2015: 2). With optimal funding management at the Jember Area Syariah Bank, ROA will be expected to increase. ROA (Return on Assets) which is a measure of the ability of bank management in obtaining profits (profits) as a whole. The results of this study support the 
research of Achmad (2018), who found that there was a positive effect of diversification based on economic sectors on ROA.

\section{Conclusion}

After analyzing the data, several conclusions can be drawn, namely:

a. The quality of current productive assets partially has a significant positive effect on the performance of Bank Syariah Mandiri in Jember Area, which is proxied by ROA.

b. The quality of earning assets under special attention partially has a significant negative effect on the performance of Bank Syariah Mandiri Area Jember.

c. The quality of earning assets is substandard partially and has a significant negative effect on the performance of Bank Syariah Mandiri Area Jember which is proxied by ROA.

d. The quality of earning assets is doubtful partially having a significant negative effect on the performance of Bank Syariah Mandiri Area Jember.

e. The quality of the non-performing earning assets partially has a significant negative effect on the performance of Bank Syariah Mandiri in Jember Area, which is proxied by RAO.

f. Funding proxies with DPK partially have a significant positive effect on the performance or ROA of Bank Syariah Mandiri in Jember Area.

\section{Bibliography}

[1.] Achmad Khomarudin. 2018. Analysis of the Effect of Funding Diversification on Profitability and Non-Performing Financing (NPF) Case Studies in Islamic Banking in Indonesia. Sunan Kalijaga Thesis Yogyakarta.

[2.] Asiyah, Binti Nur. 2017. Effect of Financing Portfolio Quality on the Profitability of Bank Mega Syariah. An Nisbah Volume 03, No.02, April 2017.

[3.] Brigham, Eugene F. And J.F. Houston. 2017. Fundamentals of Financial Management. 11. Jakarta Edition: Four Salemba.

[4.] Hanafi. 2007. Mamduh $\mathrm{H}$ and A. Halim. 2007. Analysis of Financial Statements. Issue 3. Yogyakarta: UPP STIM YKPN Publisher.

[5.] Hidayat, W.Y., Kakinaka, M., Miyamoto, H. 2012. Bank Risk and Non-Interest Income Activities in the Indonesian Banking Industry. Journal of Asian Economics.

[6.] Friday. 2006. Analysis of Financial Statements. Jakarta: PT. Earth Literacy.

[7.] Cashmere. 2014. Analysis of Financial Statements, First Edition, Seventh Printing. Jakarta: PT. Rajagrafindo Persada.

[8.] Kuncoro. 2001. How to Use and Mean Analysis of Assumptions. Classic, First Printing. Bandung: ALFABETA. 